\title{
OBITUARY
}

\section{HAROLD BARR GRIMSDALE}

IT is with very great regret that we record the death of Mr. Harold Grimsdale on May 5. Born in November, 1866, he was a younger son of T. F. Grimsdale, M.D., of Liverpool, who was very well known as an obstetrieian in the North of England in the last century. His education was received at Winchester, Caius College, Cambridge, and St. George's Hospital. At school he was in VIth Book under Ridding, who later became Bishop of Southwell, for whom he had a great admiration; he always retained very happy memories of his school life and it was there that he acquired the habit of speaking and writing good English. He shot for the school and was captain of the eight during his last year. He also won the school foils twice and was prominent in the gymnasium, but unlike his elder brother, T. B. Grimsdale, who was in the Uppingham eleven and later played occasionally for Lancashire, he made no mark in cricket. At Cambridge he took up rowing, stroked the Caius boat and took a 2nd class in the Natural Sciences Tripos. At St. George's, he continued to row and was one of the founders and first editors of the Hospital Gazette. Grimsdale took the Cambridge M.B. in 1892 and was house physician at St. George's. Oddly enough he was never house surgeon. The retirement of Brudenell Carter at about this time left Frost single handed in the ophthalmic department and Grimsdale was chosen ophthalmic registrar and at the same time went to Moorfields to work under William Lang, whose chief clinical assistant he became. Like all who worked with Lang he had a profound admiration for his clinical ability. He took the F.R.C.S.Eng. in 1894 and was elected assistant ophthalmic surgeon at St. George's, and towards the end of last century he joined the staff of the Royal Westminster Ophthalmic Hospital. He became a member of the Ophthalmological Society in 1894, served a term on the council and was later vice-president.

Life was a struggle in his early days and he combined his ophthalmic work with the teaching of anatomy. Grimsdale was a remarkably good anatomist and an excellent teacher. His methods were Socratic tinged with sarcasm; for seven years he was responsible for the teaching of a large class in anatomy and his students remained his friends for life.

In 1906 he succeeded to the senior post at St. George's and served his full time becoming consulting ophthalmic surgeon on retirement. $\mathrm{He}$ felt his severance with active work at St. George's very keenly.

During all these years he was building up a very large consulting practice. His patients realized that he was thoroughly in eàrnest and most conscientious in his work and many of them remained his friends through life. He contributed a number of papers and case 
reports to current ophthalmic literature and was the author of three books; but always professed that he was not fond of writing. This was a pity, for no one could write better than himself. Early in his career be brought out a small book on refraction; this was followed by a students' handbook of ophthalmic operations, based on the course he gave at the Royal Westminster Ophthalmic Hospital. This last work was later elaborated with the help of Elmore Brewerton into their well known handbook. It has gone into its third edition and maintains its place among the books which an ophthalmic surgeon must have at his command.

Grimsdale was an extremely generous man, no trouble was too great for him to take to help a patient or colleague and only the recipients of his generosity can know what a tremendous amount of work he did for small or no fees. For years he was surgeon to the Royal Normal College for the Blind and to the Artists' Annuity Fund and Governesses Renevolent Institution. He was a member of the Departmental Committee for the Blind in 1917 and was proud of his association with this work.

As a hospital officer Grimsdale was the most regular and punctual in his attendance of anyone the writer ever met. He was hardly ever absent save for occasional minor illnesses and he nearly always did the major share of the work himself. Besides this he taught regularly twice a week at St. George's.

As a surgeon I should say that he tended towards conservatism. He did not rush at new methods of treatment, but if, after due consideration, he thought a method worth trying he gave it a good trial. In his early years he was inclined, I think, towards the French school. His surgical technique was of a very high standard. $\mathrm{He}$ was best at cataract extraction. His extractions were models of neatness and the results excellent. His results also were góod in glaucoma cases. He was a keen supporter of Lagrange's work on sclerecto-iridectomy and it was some time before he took to trephining. Another subject in which he was much interested was retinal detachment and most of these cases were admitted for igneous puncture. Unfortunately, before Gonin's work, we did not know the importance of sealing the hole and so far as I remember he only had an occasional successful result. Plastic surgery of the eyelids was another field in which he was pre-eminent. Though extremely reserved he had a keen sense of humour and thoroughly enjoyed a joke. He was a good amateur water-colour artist, a gift he inherited from his mother. Besides this he was a facile writer of light verse. Most of these contributions appeared in the hospital gazette and all were unsigned. I remember a very clever skit he did in the style of the Ingoldsby legends.

Towards middle age Grimsdale took up golf. He used to play at Northwood most Sundays. Though never becoming a scratch 
player he was deadly accurate and he had, for his opponent, a most annoying habit of holing short shots from the edge of the green. To this journal Grimsdale contributed papers and abstracts of current Italian literature. He also read Spanish.

During the London air raids his house was demolished and we fèar that his death must be largely attributed to the effects of the war. What it must have meant to him to lose the records of nearly fifty years of work as well as his furniture and fine collection of china only those who knew him can appreciate.

Mr. Grimsdale married Miss Mabel Todd in 1903. There were no children of the marriage. The ophthalmic fraternity will wish to express their sincere sympathy with his widow in her bereavement.

\section{EMIL DE GROSZ}

DE GRosz, who died at Budapest recently at the age of 77 years, was of the third generation of a family of ophthalmologists. His grandfather, a doctor of philosophy of Budapest University and a doctor of medicine of Vienna University, founded and maintained at his own expense an eye hospital in one of the provincial towns of Hungary. He was succeeded there by his son who became chief medical officer of the city, Nagyvarad, now a Rumanian possession. The grandson, Emil de Grosz, is the subject of this notice.

He was one of the best known medical men in Europe. He was a member of the Ophthalmological Society of the United Kingdom, and of the Ophthalmologicat Societies of Germany, France and Belgium. He was an honorary.member of the Ophthalmic Section of the Royal Society of Medicine and of the Ophthalmological Societies of Egypt, Brazil, Spain and Italy. He was also an honorary fellow of the American College of Surgeons and an honorary member of the American Academy of Ophthalmology and Otolaryngology. $\mathrm{He}$ was entitled to wear numerous decorations, both national and foreign.

He became professor and director of the No. 1 Ophthalmological Clinic at Budapest in 1905. In 1909 he was chief secretary of the XVI International Medical Congress held at Budapest, when some of us, who had already made his acquaintance, became warmly attached to him. In 1914 he became for a period Dean of the Medical Faculty at Budapest. In 1929 the XIII -International Congress of Ophthalmology instituted the International Organization against Trachoma of which de Grosz became the first President; the first meeting of the Organization was held at Geneva in the following year, and subsequently annual meetings were held during his five years' tenure of the office.

During his long professional life de Grosz published many original articles, the most important of which are those on trachoma and on 